\title{
FIRST RECORD OF THE BLUE STRIPED HERMIT CRAB, CLIBANARIUS LONGITARSUS (DECAPODA, CRUSTACEA) FROM SUNDERBANS MANGROVE FOREST, BANGLADESH
}

\author{
Mostafa Ali Reza Hossain, M Niamul Naser ${ }^{1}$, M Golam Quader Khan, Mst. Kaniz \\ Fatema $^{2}$, Muhammad Abdur Rouf ${ }^{3}$, Selina Sultana ${ }^{4}$ and Muhammed Noman ${ }^{4}$ \\ Department of Fisheries Biology and Genetics, Bangladesh Agricultural University \\ Mymensingh, Bangladesh
}

\begin{abstract}
Blue Stripped hermit crab, Clibanarius longitarsus (De Haan, 1849) was collected from Kalagachhia, Satkhira Forest Range of Sundarban Mangrove Forest on 18 April 2015 during an exploration of the IUCN Crustacean Exploration Team. This crustacen decapod was recorded for the first time from Bangladesh geographical area.
\end{abstract}

Key words: Blue Striped Hermit crab, first record, Bangladesh

\section{INTRODUCTION}

Presently the family Diogenidae, commonly referred to as 'left-handed hermit crab', as many species have a bigger left claw includes some of the largest, most colourful and most conspicuous marine crabs. McLaughlin et al. (2010) recorded a total of twenty genera of the Diogenidae hermit crab worldwide, except for Arctic and Antarctic seas. They are recorded from a wide range of habitats, ranging from freshwater of river mouth and intertidal mangrove swamps to coral reefs and deeper offshore waters. They are known to be available to depths of around $300 \mathrm{~m}$ on the continental shelf (Davie, 2002)

The Blue Striped Hermit Crab (Clibanarius longitarsus) under the family Diogenidae is common in Indo West Pacific tropical mangroves. The species is generally found in the Indo West-pacific tropical mangrove forests and recorded from a number of countries (Richmond, 1997), but it was not recorded before from Bangladesh. The Blue-Stripped Hermit Crab, Clibanarius longitarsus (De Haan, 1849) was collected from Sunderbans mangrove forest at Kalagachhia, Satkhira forest range on 18 April 2015 during an exploration survey by the IUCN updating Red List Bangladesh (Crustacean), and was recorded for the first time in Bangladesh. The details of the specimens are described in this paper.

\section{MATERIAL AND METHODS}

IUCN Bangladesh started "Updating Species Red List of Bangladesh" by revisiting and reviewing first Red List published in 2000. In the first Red List,

\footnotetext{
${ }^{1}$ Department of Zoology, Faculty of Biological Sciences, University of Dhaka, Dhaka, Bangladesh; 2Department of Fisheries Management, Bangladesh Agricultural University, Mymensingh, Bangladesh; ${ }^{3}$ Fisheries and Marine Resource Technology Discipline, Khulna University, Khulna; ${ }^{4}$ IUCN Bangladesh Country Office, Dhaka, Bangladesh.
} 
crustaceans were not included. Therefore, for the crustaceans, it was first ever initiative to evaluate and determine their biodiversity status, population size and trend, national abundance, home range, habitat condition, threats and ongoing conservation initiatives. Under the initiative, there were a number of exploration surveys in several geo locations of Bangladesh. Under the present survey the exploration team visited south-west coast of several Sundarban districts including Kalagachhia, Satkhira Forest Range of Sundarban Mangrove Forest on 18 April 2015.

A number of crabs were collected from the rooted web of mangrove and mangrove forest floor. The team identified the crab as Blue Striped Hermit Crab (Clibanarius longitarsus) under the family Diogenidae one of the Crustacean Decapod of the Phylum Arthropoda for the first time recorded from Bangladesh geographical area. The GPS map of the location is shown in Fig. 1. They occur in the more open and uncovered areas of the mangroves, often nearer the seafront at the edge of sandy areas (Plate. 1). The species was identified after Low and Tan (2010), ITIS (2015).

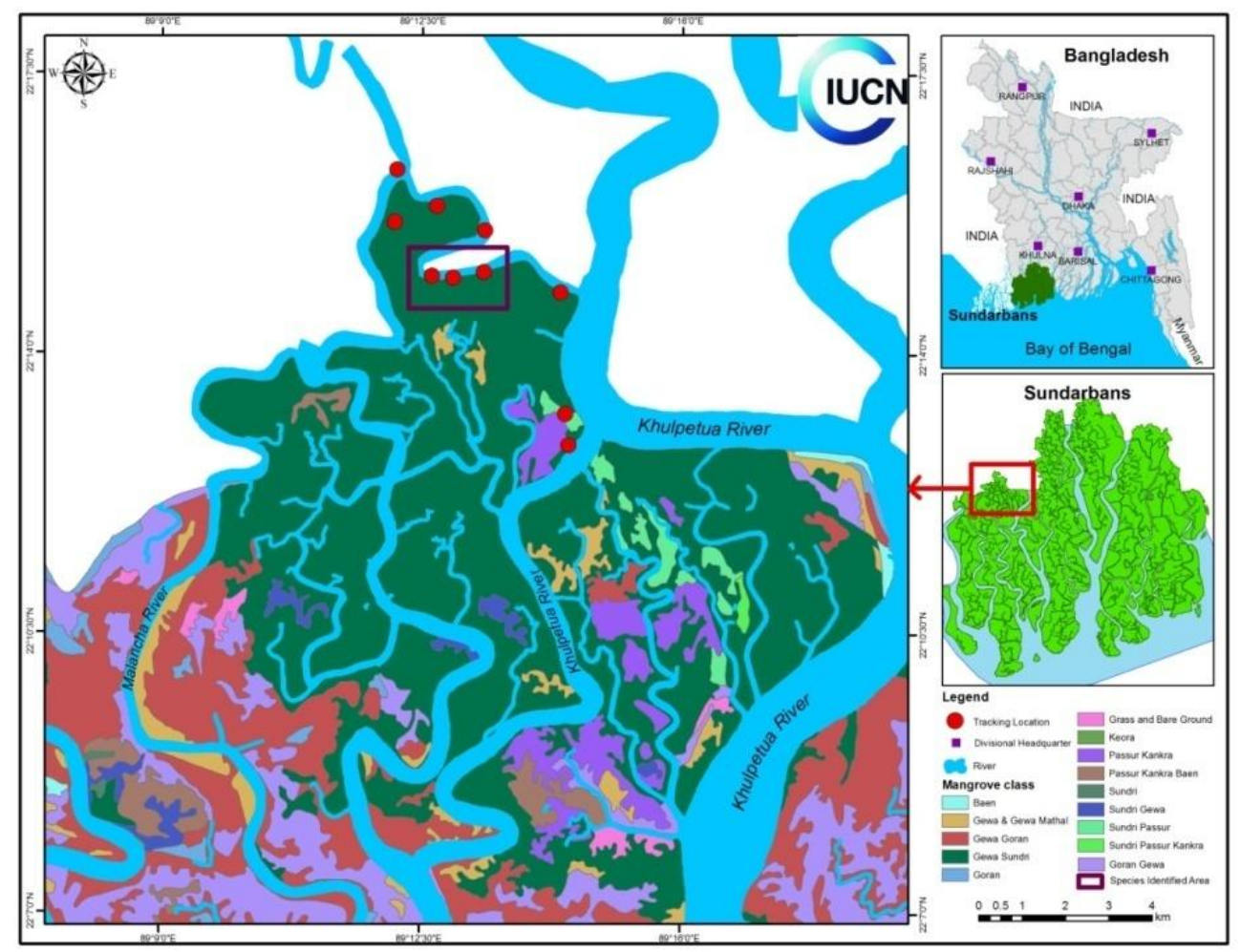

Fig. 1. Map of the location of (shown in red) collection of Blue-Stripped Hermit Crab, Clibanarius longitarsus from the Sunderbans 


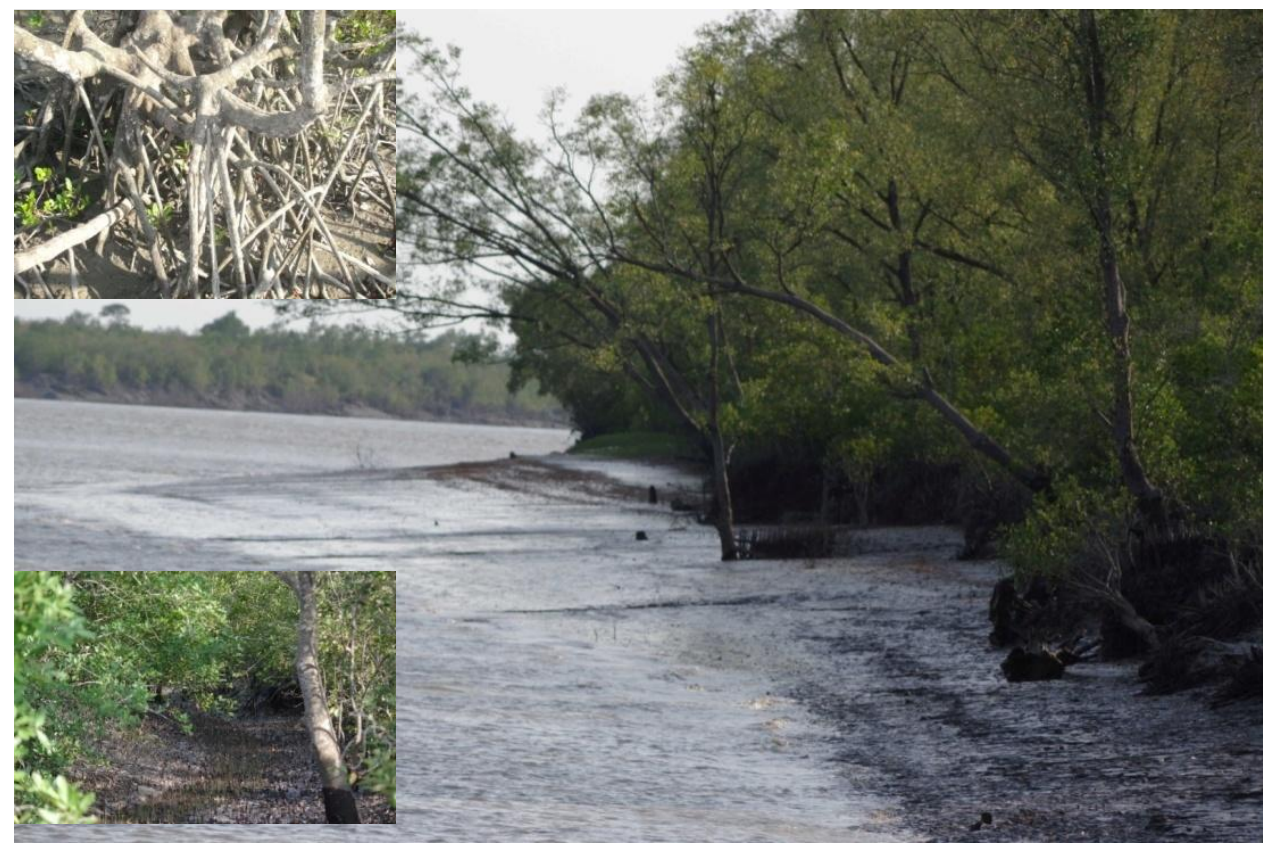

Plate 1. Habitat of the Blue Stripped Hermit Crab (Clibanarius longitarsus) at Kalagachhia, Sundarban (inset photo - close up of the rooted web of mangrove and mangrove forest floor

\section{RESULTS AND DISCUSSION}

The collected species were confirmed as the adult form of Clibanarius longitarsus after carefully analyzing their morphological features. Both pincers are roughly equal in size and held so that the 'fingers' open horizontally in front of the crab. Pincers is sparsely hairy, without stripes and with olive or brown with paler blue or bluish-green pimples. Walking legs are sparsely hairy, bluishgreen to olive-tan, with two stripes which are olive or brown, areas between stripes was whitish-tan. Short antennae and long antennae are dull brown or olive. The full taxonomic classification is as follows (after Integrated Taxonomic Information System, 2015) -

\begin{tabular}{|cl|}
\hline Phylum & Arthropoda \\
Subphylum & Crustacea \\
Class & Malacostraca \\
Subclass & Eumalacostraca \\
Order & Decapoda \\
Suborder & Pleocyemata \\
Family & Diogenidae \\
Genus & Clibanarius \\
Species & Clibanarius longitarsus \\
\hline
\end{tabular}




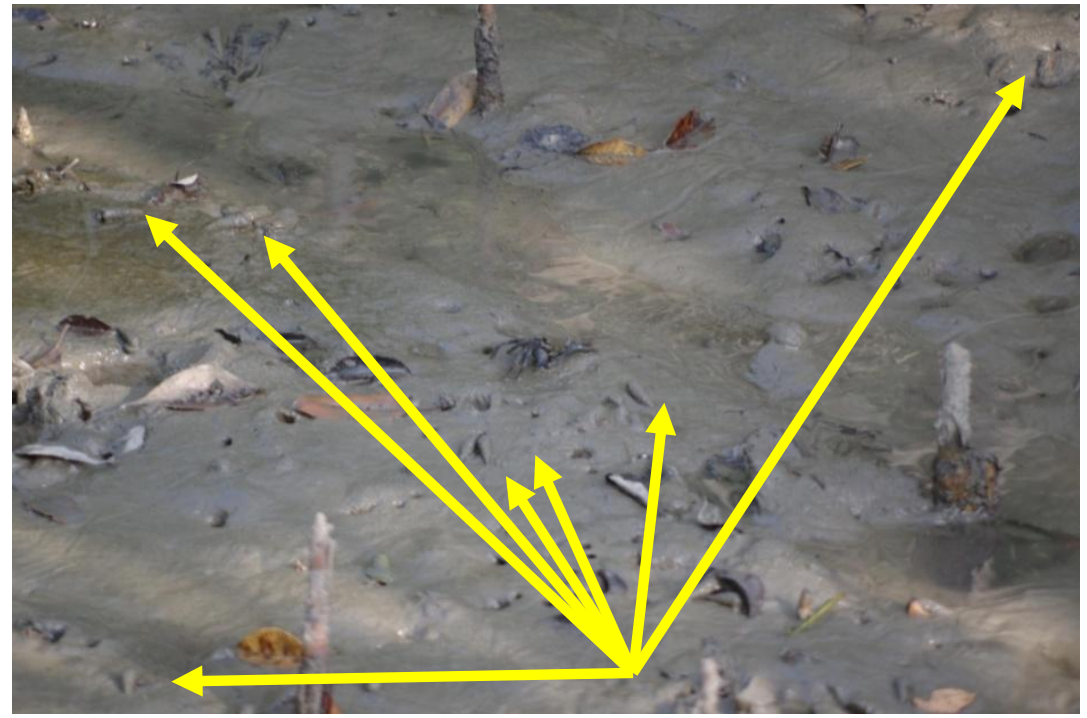

Plate 2. Sunadaban mangrove forest floor with a number of Blue Stripped Hermit Crab (Clibanarius longitarsus) each inside a gastropod shell

Unlike typical crabs, the posterior part of hermit crab bodies is soft and as such, they use discarded shells for protection (Ramesh et al., 2009). During the survey, a number of Blue Stripped Hermit Crabs were found in the mangrove floor each inside a gastropod shell (Plate 2). Like other Hermit crabs, bluestripped hermit crab never kills the original occupant of the shell and they only use dead shell. As they grow larger, the crabs look for and move into larger shells. C. longitarsus is easily identified by its blue striped legs (Plate 3) and can be spotted by looking for fast-moving snail shells that rock back and forth instead of gliding smoothly over the mud (Rahayu, 2000).

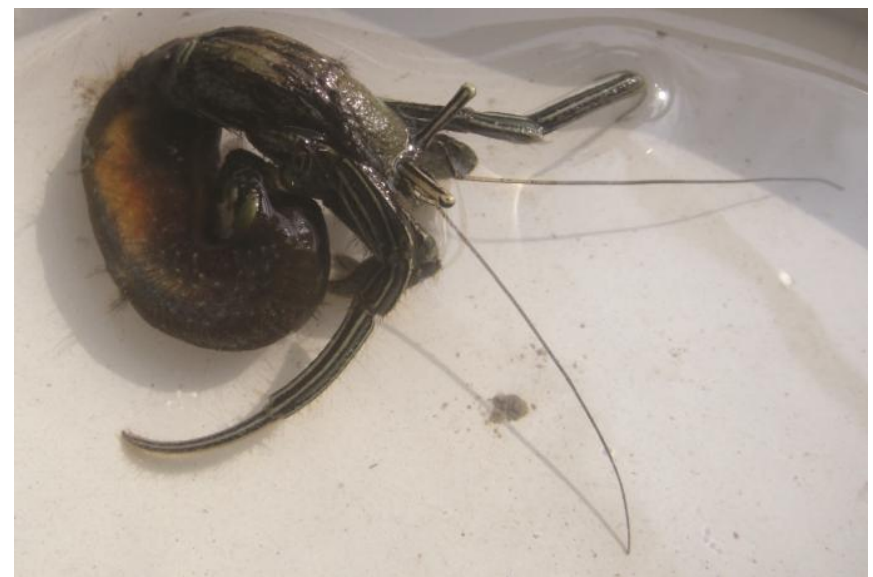

Plate 3. Adult Blue Stripped hermit crab (Clibanarius longitarsus) collected from the Sundarban Mangrove Forest 
Ecologically Blue Stripped hermit crabs play crucial roles in the mangrove ecosystem. They can be used in toxicity studies very effectively (Lyla and Khan, 2011). Birds can prey them out of their shells to eat them. The hermit crabs are scavengers and help quickly to recycle dead matter on the shores. One of the factors limiting their population is the availability of suitable empty shells (Lim et al., 1994). Therefore, local inhabitants, fishers, other forest dwellers and tourists should always think twice before removing or destroying dead shell from the floor of the Sundarban Mangrove Forest.

\section{LITERATURE CITED}

De HAAN, W. 1849. Crustacea Elaborante, in SIEBOLD, P. F. VON. Fauna Japonica 6 xxi $+230 \mathrm{p}$.

DAVIE, P.J.F. 2002. Crustacea: Malacostraca: Eucarida (Part 2): Decapoda-Anomura, Brachyura. Zoological Catalogue of Australia 19 (3B): 1-656.

ITIS. 2015. Integrated Taxonomic Information System (ITIS) (http://www.itis.gov). Retrieved on 05.05.2015.

LIM, S., NG, P., TAN, L., and CHIN, W. Y. 1994. Rhythm of the Sea: The Life and Times of Labrador Beach. Singapore: Nanyang Technological University and National University of Singapore. $160 \mathrm{p}$.

LYLA, P. S. and KHAN, S. A. 2011. Patterns of accumulation of heavy metals (Copper and Zinc) in the estuarine hermit crab Clibanarius longitarsus (De Haan). Indian Journal of Geo-Marine Sciences 40(1): 117-120.

McLAUGHLIN, P.A., KOMAI, T., LEMAITRE, R., and RAHAYU, D.L. 2010. Annotated checklist of anomuran decapod crustaceans of the world (exclusive of the Kiwaoidea and families Chirostylidae and Galatheidae of the Galatheoidea). Part ILithodoidea, Lomisoidea and Paguroidea. In: M.E.Y.

LOW and S.H. TAN (eds.). 2010. Checklists of anomuran decapod crustaceans of the world (exclusive of the Kiwaoidea and families Chiro- stylidae and Galatheidae of the Galatheoidea) and marine lobsters of the world. The Raffles Bulletin of Zoology (Supplement) 23: 5-107.

RAMESH, S., SAMIPILLAI, S. S. and ELANGOMATHAVAN, R. 2009. Habitat diversity of hermit crab Clibanarius longitarsus (De Haan) in Vellar estuary, southeast coast of India. Recent Research in Science and Technology 1(4): 161-168.

RICHMOND, M. (Ed.) 1997. A guide to the seashores of Eastern Africa and the Western Indian Ocean islands. Sida/Department for Research Cooperation, SAREC: Stockholm, Sweden. 